Article

\title{
June Temperature Trends in the Southwest Deserts of the USA (1950-2018) and Implications for Our Urban Areas
}

\section{Anthony Brazel}

School of Geographical Sciences \& Urban Planning, Arizona State University, Tempe, AZ 85287-5302, USA; abrazel@asu.edu

Received: 7 November 2019; Accepted: 9 December 2019; Published: 11 December 2019

\begin{abstract}
Within the United States, the Southwest USA deserts show the largest temperature changes (1901-2010) besides Alaska, according to the most recent USA National Climate Assessment report. The report does not discuss urban effects vs. regional effects that might be evident in trends. Twenty-five temperature stations with ca. 68-year records (1950 to 2018) have been accessed from US Global Historical Climate Network archives. Land cover data are accessed from a National Land Cover Database. June results considering both urban and rural sites show an astounding rate per year change among sites ranging from -0.01 to $0.05^{\circ} \mathrm{C}$ for maximum temperatures and 0.01 to $0.11{ }^{\circ} \mathrm{C}$ for minimum temperatures $\left(-0.8\right.$ to $3.2^{\circ} \mathrm{C}$, and 0.8 to $8.0^{\circ} \mathrm{C}$ for the entire period). For maximum temperatures, almost half of the sites showed no significant trends at a stringent 0.01 level of statistical significance, but 20 of 25 were significant at the 0.05 level. For minimum temperatures, over $75 \%$ of sites were significant at the 0.01 level (92\% at 0.05 level of significance). The urban-dominated stations in Las Vegas, Phoenix, Tucson, and Yuma show large minimum temperature trends, indicating emerging heat island effects. Rural sites, by comparison, show much smaller trends. Addressing heat in our urban areas by local actions, through collaborations with stakeholders and political resolve, will aid in meeting future urban challenges in this era of projected global climate change and continued warming.
\end{abstract}

Keywords: June mean monthly maximum and minimum temperatures; desert SW USA; trends; urban; rural areas; local climate zones; land cover

\section{Introduction}

The purpose of this paper is to present a view of the past ca. 68 years of temperature changes for the two desert areas of the Southwest USA (see Figure 1-these are the Mojave desert in Nevada and California, and the Sonoran desert in California and Arizona). The emphasis is on noting that in [1], no temperature trends comparing urban vs. rural sites are explicitly analyzed. In some earlier work prior to 1990 [2,3], substantial effects of urbanization on within temperature time series data in the Southwest and USA were identified. The recent national assessment [1] does, however, present ideas on urban vulnerabilities that are expected, and temperature changes of some individual sites are illustrated. For Las Vegas, Phoenix, and Tucson, there has been a large focus on climate and sustainability research in the past couple of decades (e.g., [4-7]). Future scenario data for SW USA show that significant changes are to come both for temperatures and precipitation in addition to changes that have already taken place $[1,8,9]$. As major population growth ensues and issues of water availability, energy, air quality, and health further intensify in the Southwest, increasing attention should be given to climate changes that the populous will experience in cities $[10,11]$. Urban area temperature rates of change are already an order of magnitude greater than rural areas, as demonstrated below, and, thus, it is imperative that 
more specific attention be given to changes for urbanized regions. It is gratifying to know that the emphasis on climate change in cities is apparently to come in more detail as part of the goals of [12].



Figure 1. Five climate divisions designated by National Ocenaic and Atmospheric Administration (NOAA), individual stations, four major urban locations of Las Vegas, Phoenix, Tucson, and Yuma (see Tables 1-3).

The two deserts are shown together with five NOAA climate divisions (see Figure 1 for climate divisions and individual sites used). Essentially, parts of CA-7 and NV-4 divisions represent the Mojave, while parts of southern CA-7, AZ-5, 6, and parts of 7 represent the Sonoran desert. To round out AZ-7, data for some sites adjacent to the Sonoran desert are used in SE Arizona. This paper explores the results of trend analysis for the period 1950-2018 for these divisions and individual sites with data from $[13,14]$. There are 25 sites with near full records (90\% complete) over the period 1950-2018 chosen from within these divisions, particularly the four largest urban areas of Las Vegas (NV), Phoenix, Tucson, and Yuma (AZ). In summer, mean monthly maximum temperatures typically exceed $38^{\circ} \mathrm{C}$ $\left(100^{\circ} \mathrm{F}\right)$ across both deserts, and the Mojave is the scene of the world's highest recorded temperature of $56.6^{\circ} \mathrm{C}\left(134^{\circ} \mathrm{F}\right)$ at Death Valley at $-59 \mathrm{~m}$ below sea level (\#18 in Figure 1). The overall region receives little rainfall on average, but the Sonoran desert does experience a so-called summer monsoon, with secondary amounts of rainfall in winter $[15,16]$. Summer rains usually commence in July. The Mojave, by contrast, does not have a summer monsoon regime but does receive winter precipitation. Values range from close to 0.0 to over $250 \mathrm{~mm}$ per year across these deserts with elevation effects on moisture and temperature from place to place. The sites range in elevation from below sea level to over $1400 \mathrm{~m}$. The month of June is chosen for this paper, as a clearer signal of the urban effect on temperature change may typically be detected due to clearer, calmer weather and fewer precipitation effects on urban temperature changes during this month. Mean monthly maximum and minimum June temperatures are analyzed at the divisional scale and for individual sites across the region. The region is dominated by dry subtropical air masses, especially in the month of June [17]; however, temperature variability relates significantly to changing frequencies of several synoptic types through time, as discussed below. 
Table 1. Stations used in analysis and descriptors of location.

\begin{tabular}{|c|c|c|c|c|c|}
\hline STATION ID & NAME & MAP CODE & LATITUDE $\left(^{\circ}\right)$ & LONGITUDE $\left(^{\circ}\right)$ & ELEVATION (m) \\
\hline \multicolumn{6}{|c|}{ ARIZONA } \\
\hline USC00020287 & ANVIL RANCH & 1 & 31.979 & -111.384 & 841 \\
\hline USC00020949 & BOUSE & 2 & 33.943 & -114.024 & 282 \\
\hline USC00021314 & CASA GRANDE NM & 3 & 32.995 & -111.537 & 433 \\
\hline USW00093026 & DOUGLAS BISBEE INT AP & 4 & 31.458 & -109.606 & 1251 \\
\hline USC00024829 & LAVEEN 3 SSE & 5 & 33.337 & -112.147 & 346 \\
\hline USC00025924 & NOGALES $6 \mathrm{~N}$ & 6 & 31.455 & -110.968 & 1055 \\
\hline USC00026132 & ORGAN PIPE CACTUS NM & 7 & 31.956 & -112.800 & 512 \\
\hline USW00023183 & PHOENIX AIRPORT & 8 & 33.428 & -112.004 & 337 \\
\hline USC00027390 & SAFFORD AG CENTER & 9 & 32.815 & -109.681 & 900 \\
\hline USC00028499 & TEMPE ASU & 10 & 33.426 & -111.922 & 356 \\
\hline USC00028619 & TOMBSTONE & 11 & 31.712 & -110.069 & 1420 \\
\hline USW00023160 & TUCSON INT AP & 12 & 32.131 & -110.955 & 777 \\
\hline USC00029334 & WILLCOX & 13 & 32.255 & -109.837 & 1271 \\
\hline USW00003145 & YUMA MCAS & 14 & 32.650 & -114.617 & 65 \\
\hline USW00003125 & YUMA PROVING GROUND & 15 & 32.836 & -114.394 & 99 \\
\hline \multicolumn{6}{|c|}{ CALIFORNIA } \\
\hline USW00023158 & BLYTHE ASOS & 16 & 33.619 & -114.714 & 120 \\
\hline USW00023161 & BARSTOW DAGGETT AP & 17 & 34.854 & -116.786 & 584 \\
\hline USC00042319 & DEATH VALLEY & 18 & 36.462 & -116.867 & -59 \\
\hline USC00043855 & HAYFIELD PUMPING PLANT & 19 & 33.704 & -115.629 & 418 \\
\hline USC00044223 & IMPERIAL & 20 & 32.849 & -115.567 & -20 \\
\hline USW00023179 & NEEDLES AIRPORT & 21 & 34.768 & -114.619 & 271 \\
\hline USC00049099 & TWENTYNINE PALMS & 22 & 34.128 & -116.037 & 602 \\
\hline \multicolumn{6}{|c|}{ NEVADA } \\
\hline USC00262243 & $\begin{array}{l}\text { DESERT NATIONAL } \\
\text { WILDLIFE RANGE }\end{array}$ & 23 & 36.438 & -115.360 & 888 \\
\hline USW00023169 & LAS VEGAS INT AP & 24 & 36.072 & -115.163 & 665 \\
\hline USC00267369 & SEARCHLIGHT & 25 & 35.466 & -114.922 & 1079 \\
\hline
\end{tabular}

Table 2. June division temperature data, linear regression of temperature on time (year) showing $\mathrm{r}$ values and significant levels (sig), and correlations with Dry Tropical and Dry Moderate June synoptic air mass frequencies (defined in the text). ${ }^{*}$ correlation $r$ value and significance level-temp vs. year; ** correlation r value-temp vs. SSC Type air mass frequency.

\begin{tabular}{|c|c|c|c|c|c|c|c|}
\hline \multicolumn{6}{|c|}{ Mean 1950-2018 } & \multirow{2}{*}{$\begin{array}{c}\text { DM } \\
r^{* *}\end{array}$} & \multirow{2}{*}{$\begin{array}{l}\text { DT } \\
\mathrm{r}^{* *}\end{array}$} \\
\hline Division & $\mathrm{T}_{\max }{ }^{\circ} \mathrm{C}$ & $\mathrm{r}^{*}$ & sig* & ${ }^{\circ} \mathrm{C} /$ year & $\mathrm{N}$ years change $\left({ }^{\circ} \mathrm{C}\right)$ & & \\
\hline AZ-5 & 38.8 & 0.42 & 0.000 & 0.033 & 2.28 & -0.81 & 0.55 \\
\hline AZ-6 & 38.3 & 0.36 & 0.002 & 0.025 & 1.73 & -0.61 & 0.27 \\
\hline AZ-7 & 34.7 & 0.43 & 0.000 & 0.028 & 1.93 & -0.68 & 0.41 \\
\hline CA-7 & 34.4 & 0.40 & 0.001 & 0.035 & 2.42 & -0.67 & 0.73 \\
\hline NV-4 & 34.8 & 0.39 & 0.001 & 0.034 & 2.35 & -0.75 & 0.82 \\
\hline Division & $\mathrm{T}_{\min }{ }^{\circ} \mathrm{C}$ & $\mathrm{r}^{*}$ & $\operatorname{sig} *$ & ${ }^{\circ} \mathrm{C} /$ year & $\mathrm{N}$ years change $\left({ }^{\circ} \mathrm{C}\right)$ & $\mathrm{r} * *$ & $\mathrm{r}^{* *}$ \\
\hline AZ-5 & 21.1 & 0.46 & 0.000 & 0.034 & 2.35 & -0.69 & 0.33 \\
\hline AZ-6 & 20.2 & 0.52 & 0.000 & 0.042 & 2.90 & -0.54 & -0.03 \\
\hline AZ-7 & 16.5 & 0.45 & 0.003 & 0.033 & 2.28 & -0.57 & 0.03 \\
\hline sCA-7 & 18.1 & 0.50 & 0.000 & 0.037 & 2.55 & -0.65 & 0.70 \\
\hline NV-4 & 19.0 & 0.61 & 0.000 & 0.048 & 3.31 & -0.51 & 0.71 \\
\hline
\end{tabular}


Table 3. Time Trends of Mean June maximum and minimum temperature by site. * correlation r value and significance level.

\begin{tabular}{|c|c|c|c|c|c|c|c|}
\hline ARIZONA & MAP CODE \# & $\mathrm{r}^{*}$ & Sig * & $\mathrm{T}_{\max } /$ Year $\left({ }^{\circ} \mathrm{C}\right)$ & $\mathrm{r}^{*}$ & Sig* & $\mathrm{T}_{\min } /$ Year $\left({ }^{\circ} \mathrm{C}\right)$ \\
\hline ANVIL RANCH & 1 & 0.20 & 0.13 & -0.013 & 0.23 & 0.08 & 0.021 \\
\hline BOUSE & 2 & 0.26 & 0.05 & 0.021 & 0.64 & 0.00 & 0.059 \\
\hline CASA GRANDE NM & 3 & 0.14 & 0.27 & 0.010 & 0.55 & 0.00 & 0.058 \\
\hline DOUGLAS BISBEE INT AP & 4 & 0.49 & 0.00 & 0.035 & 0.37 & 0.00 & 0.026 \\
\hline LAVEEN 3 SSE & 5 & 0.55 & 0.00 & 0.047 & 0.61 & 0.00 & 0.075 \\
\hline NOGALES $6 \mathrm{~N}$ & 6 & 0.43 & 0.00 & 0.035 & 0.32 & 0.01 & 0.033 \\
\hline ORGAN PIPE CACTUS NM & 7 & 0.34 & 0.01 & 0.026 & 0.49 & 0.00 & 0.048 \\
\hline PHOENIX INT AP & 8 & 0.48 & 0.00 & 0.038 & 0.79 & 0.00 & 0.113 \\
\hline SAFFORD AG CENTER & 9 & 0.38 & 0.00 & 0.026 & 0.58 & 0.00 & 0.054 \\
\hline TEMPE ASU & 10 & 0.12 & 0.36 & 0.009 & 0.65 & 0.00 & 0.099 \\
\hline TOMBSTONE & 11 & 0.30 & 0.01 & 0.024 & 0.54 & 0.00 & 0.043 \\
\hline TUCSON INT AP & 12 & 0.56 & 0.00 & 0.043 & 0.58 & 0.00 & 0.049 \\
\hline WILLCOX & 13 & 0.39 & 0.00 & 0.026 & 0.62 & 0.00 & 0.076 \\
\hline YUMA MCAS AP & 14 & 0.20 & 0.11 & 0.016 & 0.58 & 0.00 & 0.045 \\
\hline YUMA PROVING GROUND & 15 & 0.36 & 0.01 & 0.033 & 0.35 & 0.00 & 0.027 \\
\hline \multicolumn{8}{|c|}{ CALIFORNIA } \\
\hline BLYTHE ASOS AP & 16 & 0.27 & 0.03 & 0.031 & 0.16 & 0.18 & 0.012 \\
\hline BARSTOW DAGGETT AP & 17 & 0.42 & 0.00 & 0.040 & 0.48 & 0.00 & 0.043 \\
\hline DEATH VALLEY & 18 & 0.45 & 0.00 & 0.040 & 0.27 & 0.03 & 0.027 \\
\hline $\begin{array}{l}\text { HAYFIELD PUMPING } \\
\text { PLANT }\end{array}$ & 19 & 0.40 & 0.00 & 0.036 & 0.15 & 0.22 & 0.011 \\
\hline IMPERIAL & 20 & 0.31 & 0.01 & 0.025 & 0.24 & 0.05 & 0.019 \\
\hline NEEDLES AIRPORT & 21 & 0.49 & 0.00 & 0.044 & 0.57 & 0.00 & 0.048 \\
\hline TWENTYNINE PALMS & 22 & 0.12 & 0.15 & 0.016 & 0.53 & 0.00 & 0.052 \\
\hline \multicolumn{8}{|c|}{ NEVADA } \\
\hline $\begin{array}{l}\text { DESERT NATIONAL } \\
\text { WILDLIFE RANGE }\end{array}$ & 23 & 0.26 & 0.04 & 0.020 & 0.45 & 0.00 & 0.037 \\
\hline LAS VEGAS INT AP & 24 & 0.29 & 0.01 & 0.026 & 0.81 & 0.00 & 0.096 \\
\hline SEARCHLIGHT & 25 & 0.27 & 0.04 & 0.023 & 0.41 & 0.00 & 0.034 \\
\hline
\end{tabular}

\section{Data and Methods}

Two sources of climate information were accessed from the website archives of the National Oceanic and Atmospheric Administration's National Centers for Environmental Information: (a) climate division data for June for maximum and minimum temperatures [13], and (b) individual station data from Climate Data Online link, which includes Global Historical Climate Network (GHCN) sites for the month of June (maximum and minimum temperatures) for the period 1950 to 2018 [14]. Temperatures are shelter height or so-called canopy layer air temperatures (particularly important to emphasize for urban sites [18]).

Detailed information about these databases may be found in [19-22]. In addition to temperature data, several sources were investigated to learn of the impact of land cover around individual sites, especially within $500 \mathrm{~m}$ of each site [23-28]. It was not possible to trace detailed land conditions at fine resolution back to 1950 for all sites. This remains as a future goal for analysis. The main focus in this regard is on the four major urban sites in the region-Las Vegas, Phoenix, Tucson, and Yuma. Metadata of individual sites were consulted from [14] for completeness of records, station shifts during the time period, instrument changes, and modernization that occurred throughout the national network. In addition, it was possible to provide estimates of land cover and to provisionally estimate a Local Climate Zone (LCZ) associated with each of 4 major urban stations using methods of [29,30]. There are 25 stations chosen, which have the most complete records for 1950-2018, although with some missing 
data for some sites (see Figure 1). These sites were $90 \%$ complete, and no major multi-year data gaps through time in the data. Central and northern AZ areas within the Mojave desert are excluded due to incomplete temporal records. A simple linear regression trend analysis and ANOVA were performed similar to [1], and identification of significant changes and rates of temperature changes over the time period were determined. The results are presented in Tables 1-3 for divisional and individual sites.

A more specific analysis was performed for four urban locations. The natural environment is used as a rural reference and not irrigated farm fields nor suburban areas to define rural to compare with urban environments. In [31], it has been noted that sites of irrigated landscapes in comparison to dry landscapes used as a rural reference station can influence urban vs. rural temperature determination by as much as $3^{\circ} \mathrm{C}$, virtually equivalent to dimensions of urban effects on temperature. In order to achieve standardizing using desert sites as rural, distances, and elevations from desert terrain to urban sites had to range from $25-60 \mathrm{~km}$ and 34-223 m elevation differences, assuring, at the same time, that intervening terrain is typically flat between the urban and desert sites chosen. Elevation alone could affect urban versus rural temperature comparisons on the order of 0.17 to $1.0^{\circ} \mathrm{C}$ because, as illustrated below, there is a significant correlation between elevation and June mean monthly maximum and minimum temperatures among the 25 sites, but as will be seen below, these differences are relatively minor effects compared to land cover differences. All urban vs. rural comparisons include corrections for these elevation differences from the linear regression coefficient of temperature change per elevation.

The Spatial Synoptic Classification (SSC) catalog of Sheridan [32] was consulted to extract the month of June frequencies of several synoptic air mass types in order to relate to variations of temperatures for the period 1950-2018 and to learn of related shifts in frequencies in June over the 1950-2018 period [17]. The most frequent types for June in this desert region are the so-called DT (dry tropical) and DM (dry moderate). The DT (dry tropical) weather type is similar to the continental Tropical air mass; it represents the hottest and driest conditions found at any location. There are two primary sources of DT as a weather type (17): either it is advected from the desert regions, such as the Sonoran or Sahara Desert, or it is produced by rapidly descending air, whether via orography (such as the chinook effect) or strong subsidence [32]. The DM air is mild by comparison. It has no traditional analog but is often found with zonal flow in the middle latitudes, especially in the lee of mountain ranges. It also arises when a traditional air mass, such as continental Polar or maritime Tropical (MT), has been advected far from its source region and has, thus, been modified considerably (17). In [33], for the month of May over the period 1990-2004 in Phoenix, AZ, 64\% of the days were typed DT with light winds $\left(<5 \mathrm{~m} \mathrm{~s}^{-1}\right)$, and another $20 \%$ of days were DM associated with cool air intrusions related to troughs that had developed in the Western USA. Occasionally, in June, MT or MM (moist moderate) weather types do occur, but these are more typical from July to September in the SW and play a minor role in June. Generally, it holds true that when DM is prevalent, troughing over the Southwestern USA occurs with cooler upper level and surface temperatures. For example, a significant number of DM days (upwards of 5 per month) at Phoenix tend to reduce the mean monthly minimum temperature by over $1.5^{\circ} \mathrm{C}[33]$.

\section{Results}

Table 2 lists mean June temperatures for the 1950-2018 period and trend analysis of each division's June mean maximum and minimum temperature $\left(\mathrm{T}_{\max }\right.$ and $\left.\mathrm{T}_{\min }\right)$ over this time period. June $\mathrm{T}_{\max }$ averages $34.4-38.8^{\circ} \mathrm{C}$ across the divisions (some $93.9^{\circ} \mathrm{F}$ and $101.8^{\circ} \mathrm{F}$ ), with daily extremes considerably higher. At this division scale, all divisions have significant trends upwards for both June $\mathrm{T}_{\max }$ and $\mathrm{T}_{\min }$. As indicated in [1], the SW USA region has the largest summer temperature increases compared to other US regions except for Alaska, increasing $1.0-1.5^{\circ} \mathrm{C}$ in just the last few decades. Over the last almost 70 years, temperatures have changed $1.7-2.4{ }^{\circ} \mathrm{C}$ for $\mathrm{T}_{\max }$ and $2.3-3.3{ }^{\circ} \mathrm{C}$ for $\mathrm{T}_{\min }$ across these five climate divisions.

Daily catalogs of DT and DM frequencies for June for 1950-2018 are used here from [32] for Las Vegas (\#24), Barstow-Daggett (\#17), Yuma (\#14), and Tucson (\#12) to represent division synoptic 
types experienced across the region. Correlations between monthly frequencies of DT and DM, and mean monthly $\mathrm{T}_{\max }$ and $\mathrm{T}_{\min }$ for CA-7, NV-4, AZ-5, 6, and 7 were determined to learn if changes in the weather types are significantly related to temporal changes in $T_{\max }$ and $T_{\min }$ at these sites. The $\mathrm{r}$ values are listed in Table 2. This analysis provides insight into the year-to-year impacts of synoptic-scale drivers of $\mathrm{T}_{\max }$ and $\mathrm{T}_{\min }$ variations. There is a negative relation between climate division temperatures and frequency of DM weather types (DM induces cooling), similar to what was identified by [33] over a shorter 15-year time period. There is a positive effect of increases in DT weather types on $\mathrm{T}_{\max }$ and $\mathrm{T}_{\min }$ through time. However, there appears to be more variability of the strength of the regressions than for the DM type. The monthly $\mathrm{T}_{\min }$ values for AZ-6 and 7 are not significantly correlated with changes in DT, because DT percentages of days for June are exceedingly high and minor shifts do not significantly impact temperatures for the month. In CA-7, DM has decreased over time, while DT types have significantly increased. In the more northerly NV-4, no significant changes have taken place for the DM frequencies, but a positive increase in frequencies has occurred for DT. In the AZ divisions, no significant changes in DT have taken place, but significant drop offs of DM frequencies have occurred, similar to short-term changes shown in [33].

Table 3 shows the 25 sites alphabetically by state with the numbers identifying their location in Figure 1. Across the five climate divisions, from 1950-2018 June $\mathrm{T}_{\max }$ differs by 34.4 to $38.8^{\circ} \mathrm{C}$ and for $\mathrm{T}_{\min }, 16.5$ to $21.1^{\circ} \mathrm{C}$ (some $4-5^{\circ} \mathrm{C}$ spread across the five divisions for both). Among the 25 sites, $\mathrm{T}_{\max }$ ranges from 35 to $40.8^{\circ} \mathrm{C} ; \mathrm{T}_{\min }, 12.8$ to $27.4^{\circ} \mathrm{C}$ (a range of $5.8^{\circ} \mathrm{C}$ for $\mathrm{T}_{\max }$ and $14.6^{\circ} \mathrm{C}$ for $\mathrm{T}_{\min }$ ). The 25 sites are representative for the divisional $\mathrm{T}_{\max }$, but illustrate, as expected, much more spatial variability in relation to the division data for $\mathrm{T}_{\min }$. Temperature trends among the 25 stations for $\mathrm{T}_{\max }$ were significantly positive over time for 20 of the 25 sites, whereas 22 of the 25 sites showed strong significant increases over time for $\mathrm{T}_{\min }$. Holding aside the four urban sites (they are discussed

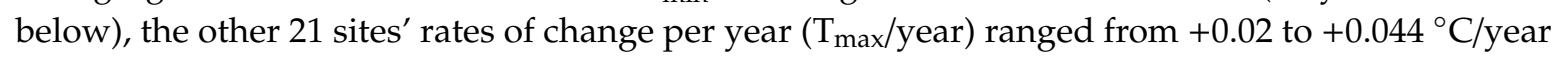
$\left(+1.4\right.$ to $+3.0^{\circ} \mathrm{C}$ over the period). For $\mathrm{T}_{\min }$, rates of change per year $\left(\mathrm{T}_{\min } /\right.$ year) ranged from +0.019 to $+0.058^{\circ} \mathrm{C}$ year (or +1.3 to $+4.0^{\circ} \mathrm{C}$ ). In [9], several sites are shown on a map as having $\mathrm{T}_{\max }$ changes on the order of $+1.5^{\circ} \mathrm{C}$ for the period $1901-2010$, and $\mathrm{T}_{\min }$ changes of $+3.0^{\circ} \mathrm{C}$ for a few sites. Thus, over the shorter, recent, albeit mostly overlapping, 68-year period, there are comparable changes equivalent to the entire 110-year period of 1901-2010. Since just 1990, changes across the sites excluding urban sites ranged from +0.8 to $2.9^{\circ} \mathrm{C}$ for $\mathrm{T}_{\max }$ and +1.0 to $+3.8^{\circ} \mathrm{C}$ for $\mathrm{T}_{\min }$. The data results indicated in Tables 2 and 3 illustrate the continuing and, in fact, increasing rates of temperature changes for non-urban locations in the SW region, especially for $\mathrm{T}_{\min }$.

Information on land cover around each of the 25 sites (urban is included) was obtained by access to [23-28], in addition to Bright Light Indices (BI) data from [25] and used by [34], an indication of the amount of urbanization. From these sources, it was possible to estimate $\%$ shrub (\% shrub), \% cropland (\% crop), \% developed land (\% dev), and density of night lights (BI) within $500 \mathrm{~m}$ of each location. Percent developed includes sub-categories open, low intensity, medium intensity, and high intensity. For this research, total developed percentages were used. These data are analyzed together with $T_{\max }$, $\mathrm{T}_{\min }, \mathrm{T}_{\max } /$ year, and $\mathrm{T}_{\min } /$ year. A correlation analysis was employed using spatial variables of latitude (LAT), longitude (LONG), elevation (ELEV), \% shrub, \% crop, \% dev, and BI (see correlation matrix in Table 4). The land cover data and light data are from the recent decade.

ELEV significantly impacts $\mathrm{T}_{\max }$ and $\mathrm{T}_{\min }$ over the 25 sites $(\mathrm{r}=-0.89$ and -0.77 , respectively) as temperature generally decreases with elevation within the region. LONG does correlate with temperatures as, from southeast to northwest across the region, there is a general downward elevation change (of ca. $1500 \mathrm{~m}$ ). LONG changes by $7^{\circ}$, whereas $\mathrm{T}_{\max }$ increases by $+2{ }^{\circ} \mathrm{C}$ and $\mathrm{T}_{\min }$ by $+5^{\circ} \mathrm{C}$. LAT changes by $5^{\circ}$ among the sites and correlates with $\mathrm{T}_{\min }(\mathrm{r}=0.43)$. The impact attains $4.7^{\circ} \mathrm{C}$ across the region. However, $\mathrm{T}_{\max } /$ year and $\mathrm{T}_{\min } /$ year do not correlate with changes in ELEV. Significant correlations resulted between $\mathrm{T}_{\min } /$ year and $\% \operatorname{shrub}(\mathrm{r}=-0.61), \% \operatorname{dev}(\mathrm{r}=0.74)$, and $\mathrm{BI}(\mathrm{r}=0.76)$. Fewer shrub environments were highly correlated with increased development and impervious surfaces around sites $(\mathrm{r}=-0.79)$. The Bright Lights Index increased with lessening \% shrub (with 
$r=-0.68$ ). These findings are consistent with expected stronger land cover effects during minimum temperature time of day than during the heat of the day. However, when excluding the four large urban sites, there are no significant relations among the land cover variables and temperature variables, as overall most sites are dominated by high shrub percentages since 1950.

Table 4. Correlation matrix of location, land cover, and temperature variables. Land cover variables defined in the text. Underlined r values significant at 0.05 level.

\begin{tabular}{|c|c|c|c|c|c|c|c|c|c|c|c|}
\hline & ELEV & $T_{\max }$ & $T_{\min }$ & $\mathrm{T}_{\max } /$ Year & $\mathrm{T}_{\min } /$ Year & LAT & LONG & $\%$ Shrub & \% Crop & $\% \operatorname{dev}$ & BI \\
\hline ELEV & 1 & $\underline{-0.89}$ & $\underline{-0.77}$ & $\underline{-0.14}$ & $\underline{-0.05}$ & -0.26 & $\underline{0.56}$ & $\underline{-0.01}$ & 0.04 & $\underline{-0.00}$ & -0.14 \\
\hline $\mathrm{T}_{\max }$ & & 1 & 0.76 & 0.10 & 0.16 & 0.18 & -0.30 & -0.03 & -0.02 & 0.04 & 0.11 \\
\hline $\mathrm{T}_{\min }$ & & & 1 & 0.36 & 0.16 & $\underline{0.43}$ & -0.52 & -0.12 & $\underline{-0.18}$ & 0.25 & 0.25 \\
\hline $\mathrm{T}_{\max } /$ year & & & & 1 & 0.01 & 0.14 & $\underline{-0.13}$ & 0.00 & $\underline{-0.24}$ & 0.16 & -0.08 \\
\hline $\mathrm{T}_{\min } /$ year & & & & & 1 & 0.14 & 0.21 & $\underline{-0.61}$ & $\underline{-0.14}$ & $\underline{0.74}$ & $\underline{0.76}$ \\
\hline LAT & & & & & & 1 & $\underline{-0.74}$ & 0.06 & $\underline{-0.14}$ & 0.03 & 0.08 \\
\hline LONG & & & & & & & 1 & $\underline{-0.29}$ & 0.24 & 0.15 & 0.08 \\
\hline$\%$ shrub & & & & & & & & 1 & -0.24 & -0.79 & -0.68 \\
\hline$\%$ crop & & & & & & & & & 1 & $\underline{-0.26}$ & -0.18 \\
\hline$\% \operatorname{dev}$ & & & & & & & & & & 1 & $\underline{0.83}$ \\
\hline $\mathrm{BI}$ & & & & & & & & & & & 1 \\
\hline
\end{tabular}

Within the five divisions there are four major cities—Las Vegas, NV (\#24), Phoenix (\#8), Tucson (\#12), and Yuma (\#14), AZ, with current populations of ca. $0.62 \mathrm{M}, 1.55 \mathrm{M}, 0.5 \mathrm{M}$, and $0.09 \mathrm{M}$, respectively. The climate data used were from major airports either central to the metropolitan areas (i.e., Las Vegas and Phoenix) or on the edge but impacted by urban growth (Tucson and Yuma). Figure 2 illustrates regional and local placement of these sites and land cover within $500 \mathrm{~m}$ and at some distance from them. The June $T_{\max }$ and $T_{\min }$ time series and urban-rural differences $\left(T_{\operatorname{maxU}} \mathrm{R}\right.$ and $\left.\mathrm{T}_{\min U-\mathrm{R}}\right)$ between the urban-affected airport sites and rural desert sites are shown in Figure 3 and listed in Table 5. Urban-rural station pairs in Table 5 are listed by \#'s in Figure 1.

Table 5. UHI estimates ( $\mathrm{T}_{\mathrm{U}-\mathrm{R}}$ ). Mean urban-rural estimates (UHI) for 1950-2018, r value of UHI trends over time, significance level, rate of change of UHI/year, and recent 2010-2018 mean UHIs. See map code pairing \#'s in (). Yuma Valley station near Yuma Airport with short record is used to show irrigated rural area comparison.

\begin{tabular}{|c|c|c|c|c|c|}
\hline UHI Estimates $\left(\mathrm{T}_{\mathrm{U}-\mathrm{R}}\right)$ & 1950-2018 & 1950-2018 & Sig Level & 1950-2018 & 2010-2018 \\
\hline Urban Area Airports & Mean $\mathrm{T}_{\mathrm{U}-\mathrm{R}}\left({ }^{\circ} \mathrm{C}\right)$ & $\mathrm{r}$ of $\mathrm{T}_{\mathrm{U}-\mathrm{R}}$ vs. Year & of $r$. & $\mathrm{T}_{\mathrm{U}-\mathrm{R}} /$ Year Rate & Mean $\mathrm{T}_{\mathrm{U}-\mathrm{R}}\left({ }^{\circ} \mathrm{C}\right)$ \\
\hline LasVegas $\mathrm{T}_{\operatorname{maxU}-\mathrm{R}}(24-23)$ & 0.20 & 0.05 & 0.709 & 0.001 & 0.90 \\
\hline LasVegas $\mathrm{T}_{\text {minU-R }}(24-23)$ & 4.79 & 0.80 & 0.000 & 0.057 & 6.50 \\
\hline Phoenix $\mathrm{T}_{\operatorname{maxU}-\mathrm{R}}(8-3)$ & -0.59 & 0.48 & 0.000 & 0.028 & -0.15 \\
\hline Phoenix $\mathrm{T}_{\operatorname{minU}-\mathrm{R}}(8-3)$ & 4.64 & 0.62 & 0.000 & 0.054 & 4.33 \\
\hline Tucson $\mathrm{T}_{\operatorname{maxU}-\mathrm{R}}(12-17)$ & -0.21 & 0.81 & 0.000 & 0.058 & 4.08 \\
\hline Tucson $\mathrm{T}_{\text {minU-R }}(12-17)$ & 3.16 & 0.56 & 0.000 & 0.031 & 1.02 \\
\hline Yuma $\mathrm{T}_{\operatorname{maxU} \mathrm{R}}(14-15)$ & -0.03 & 0.44 & 0.001 & -0.013 & 0.23 \\
\hline Yuma $T_{\operatorname{minU}-R}(14-15)$ & -0.03 & 0.52 & 0.000 & 0.017 & 0.20 \\
\hline Yuma-Yuma Valley Max & 1.10 & 0.70 & 0.000 & 0.073 & $\mathrm{n} / \mathrm{a}$ \\
\hline Yuma-Yuma Valley Min & 3.79 & 0.77 & 0.000 & 0.067 & $\mathrm{n} / \mathrm{a}$ \\
\hline
\end{tabular}



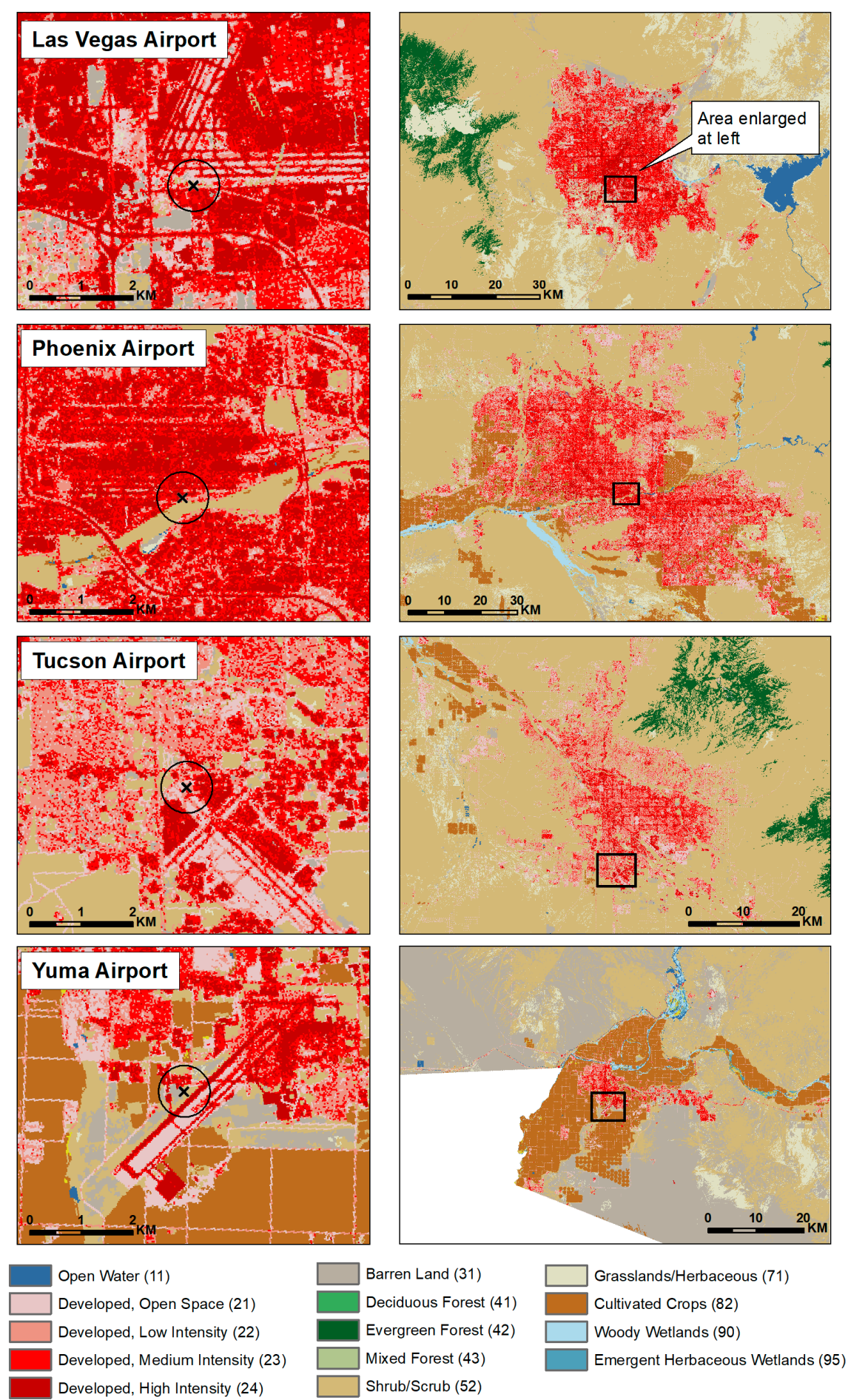

Figure 2. Four airport urban sites. Right panel shows urban extent and land cover; left panel is the zoomed-in view showing weather site placement and $500 \mathrm{~m}$ circle around each site. There have been some station moves locally within the airports over time. At times of $\mathrm{T}_{\min }$ and $\mathrm{T}_{\max }$, prevailing wind regimes show SW for Las Vegas; E (night) to W (day) for Phoenix; SE (night) to SW (day) for Tucson; and NE (night) to SW (day) for Yuma. 
Las Vegas
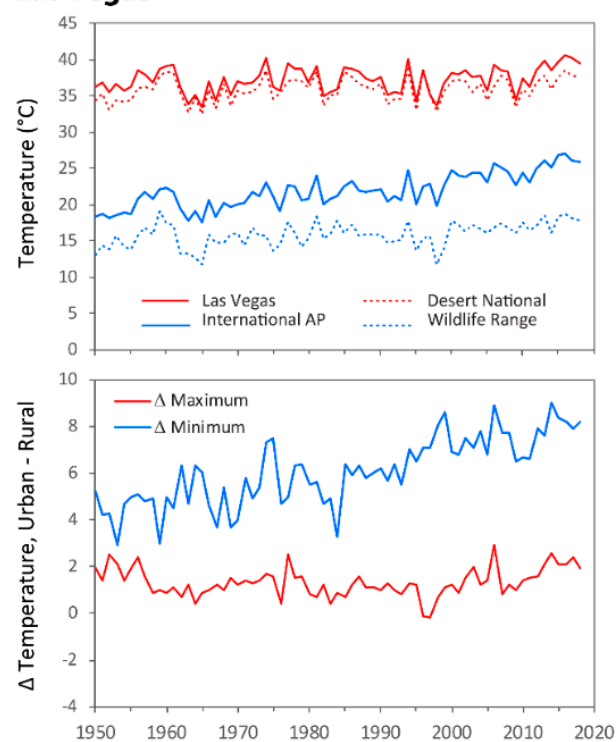

Tucson
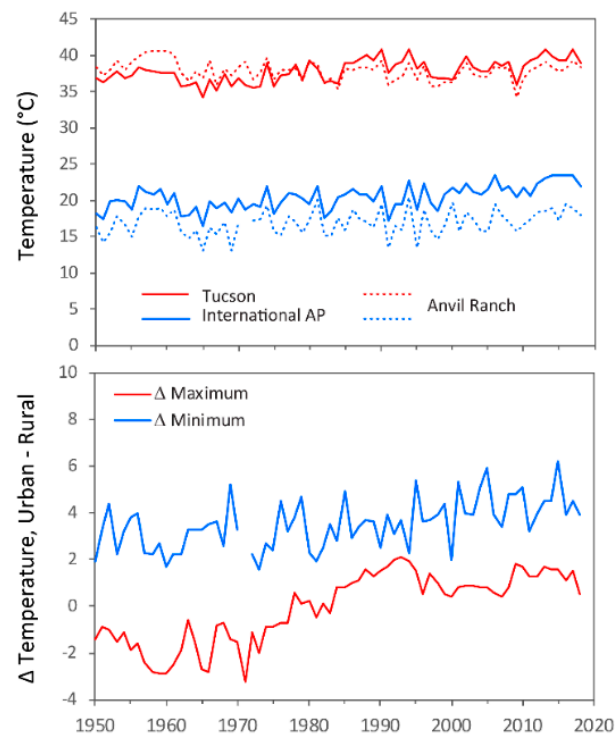

\section{Phoenix}
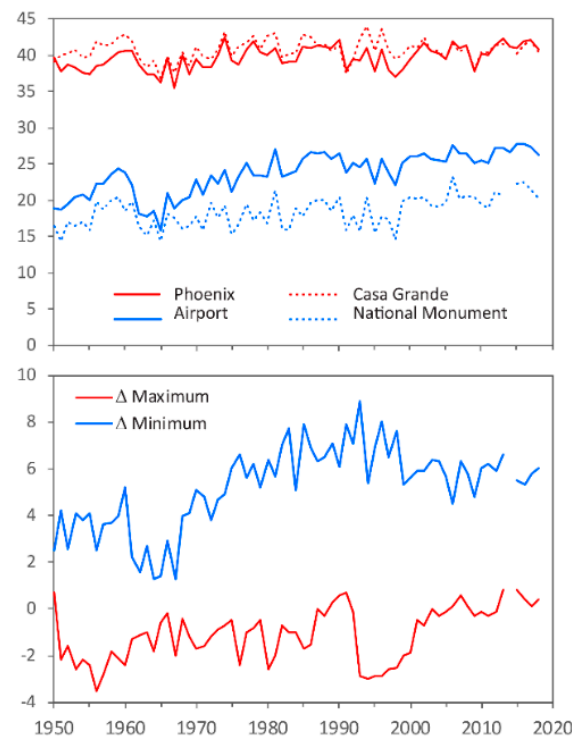

\section{Yuma}


Figure 3. Four urban airport sites and rural reference sites showing June maximum and minimum temperatures and urban-rural time series (see Figure 2). Red lines refer to maximum temperatures; blue lines, minimum temperatures. Lower panel per site provides a measure of the day and night urban-rural estimates (UHI). All values in ${ }^{\circ} \mathrm{C}$.

It should be emphasized that the airport sites, although having urban effects, are not necessarily representative of all LCZ zones found in these cities, nor the cities as a whole. A major reason is the airport geographical position within or peripheral to the cities, and because they only represent basically a few kinds of urbanized LCZs that have been recently classified by researchers [30,31]. The urban sites chosen are typical of LCZs E (which after [30], is labeled bare rock or paved) and some secondary effects of LCZ 6 and 8 (open low rise and large low rise, typical of effects of commercial buildings located on airports). The rural sites are, for the most part, LCZ C (bush, scrub desert with land cover mostly sand or bare soil). The airport sites were in LCZ C or D prior to major urbanization near and around them. In [26], for example, land cover changes for the Phoenix airport were analyzed since the airport's construction and substantiated this premise.

It is quite apparent that major temperature changes have occurred since 1950 at the urban-impacted airport sites relative to the rural desert sites, due to development near and around the airports, 
particularly for $\mathrm{T}_{\min }$ (see Figure 3). Rates of change of $\mathrm{T}_{\operatorname{maxU}-\mathrm{R}}$ and $\mathrm{T}_{\operatorname{minU}} \mathrm{R}$ (or $\mathrm{T}_{\operatorname{maxU}-\mathrm{R}} / \mathrm{year}$ and $\mathrm{T}_{\text {minU-R }} /$ year) are as follows: $+0.001,+0.028,+0.058$, and $-0.013^{\circ} \mathrm{C} /$ year for $\mathrm{T}_{\text {maxU-R}} /$ year; and +0.057 , $+0.054,+0.031$, and $+0.017^{\circ} \mathrm{C}$ for $\mathrm{T}_{\text {minU-R}} /$ year for station pairs of Las Vegas-desert, Phoenix-desert, Tucson-desert, and Yuma-desert, respectively. This corresponds to 1950-2018 overall changes of +0.07 , $+1.93,+4.0$, and $-0.90{ }^{\circ} \mathrm{C}$ for $\mathrm{T}_{\operatorname{maxU}-\mathrm{R}}$ ( $\mathrm{r}$ values for the trend analysis are $0.05,0.48,0.81$, and 0.44 , respectively, and with the exception of Las Vegas, station changes over time are statistically significant at the 0.05 level). For $\mathrm{T}_{\text {minU-R }}$ the overall changes are $+3.93,+3.73,+2.14$, and $+1.17^{\circ} \mathrm{C}$ ( $\mathrm{r}$ values are $0.80,0.62,0.56$, and 0.52 for the trend analysis and are statistically significant at the 0.05 level). The larger changes of $\mathrm{T}_{\operatorname{minU}-\mathrm{R}}$ at Las Vegas and Phoenix likely relate to their more central locales within each metropolitan area, larger airports, and larger urban area expansions through time. Tucson and Yuma sites are more peripherally located and not "surrounded" as much by urban or city surfaces (see Figure 2). At the smaller city of Yuma, the immediate grounds of the airport, in a sense, resembles desert terrain, with further away landscapes consisting of much-irrigated agriculture beyond the airport in addition to the smaller city area. Daytime changes over time are smaller than nighttime by comparison for each respective pairing, with the exception of Tucson's changes for $\mathrm{T}_{\text {maxU-R. }}$. Indeed, the $\mathrm{T}_{\text {maxU-R }}$ changes for Tucson of $+4.0^{\circ} \mathrm{C}$ may be due to station or instrument issues through time in addition to major land use changes [35]. The rates of change of $+0.057,+0.054,+0.031$, and $+0.017^{\circ} \mathrm{C}$

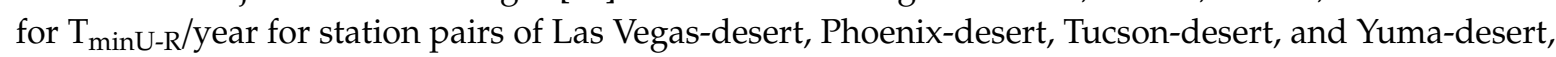
respectively, rank generally with BI Indices of 109, 94, 50, and 50 and $\% \operatorname{dev}$ land of $90 \%, 91 \%, 50 \%$, and $20 \%$. For recent data since 2010, June $\mathrm{T}_{\operatorname{maxU}-\mathrm{R}}$ and $\mathrm{T}_{\operatorname{minU} \mathrm{R}} \mathrm{R}$ values averaged +0.9 and $+6.5^{\circ} \mathrm{C}$ for Las Vegas; -0.15 and $+4.33{ }^{\circ} \mathrm{C}$ for Phoenix; +4.08 and $+1.02{ }^{\circ} \mathrm{C}$ for Tucson; and +0.23 and $+0.20{ }^{\circ} \mathrm{C}$ for Yuma. Overall, the differences of $\mathrm{T}_{\text {minU-R }}$ across the sites are generally consistent with variations of the $\mathrm{BI}$ index and \% dev values.

\section{Discussion and Conclusions}

The $\mathrm{T}_{\text {minU-R }}$ values (what might be cautiously called the UHI as represented by a specific urban LCZ) compare favorably with previous research. In [36], estimates are presented of maximum nocturnal heat island intensities for North America, Europe, and wet and dry Sub-tropical environments, with the dry Sub-tropical cities' UHIs ranging from ca. 4 to $7^{\circ} \mathrm{C}$ for populations of $0.05 \mathrm{M}$ to $5.0 \mathrm{M}$. For the cities of Las Vegas and Phoenix, $\mathrm{T}_{\text {minU-R }}$ is consistent with dry Subtropical places in Africa, India, and the Middle East cited by [36]; whereas, values for Tucson and Yuma are considerably less relative to the population, indicating their peripheral siting and their limited representation for more central urban LCZ locations in these places. In a past analysis by [37], individual stations in Phoenix indicated a range from $2-6{ }^{\circ} \mathrm{C}$ for UHI, consistent with this present analysis. As mentioned above, [31] suggest for the Phoenix UHI that values could be different by $\sim{ }^{\circ} \mathrm{C}$ depending on using dry desert versus moist agricultural irrigated surfaces as rural, indicating the importance of maintaining consistency in choosing a rural reference for the natural environmental setting. Using modeling, [6] illustrates an increase in early morning UHI of $2-3^{\circ} \mathrm{C}$, in a simulation of changing shrub landscape to urban for the Phoenix area. Similarly, [4] also simulates a $\sim 3^{\circ} \mathrm{C} \mathrm{UHI}$ for summer for Las Vegas as a whole. For Tucson [7], in a previous analysis using station data, a UHI of $\sim 3^{\circ} \mathrm{C}$ was also found using more central urban sites than the Tucson airport station as the choice of an urban site. Unfortunately, most of these sites have either been discontinued or have too short a record for long term climate change analysis. As mentioned, the landscape in the Yuma area consists of irrigated agriculture surrounding the airport station. If this agriculture area is used as a rural reference selection (what is called the Yuma Valley station) instead of desert (see Table 5), the $\mathrm{T}_{\operatorname{minU}-\mathrm{R}}$ is $3.8^{\circ} \mathrm{C}$ and, thus, becomes substantially larger than using the natural desert as a rural reference, affirming the message of [31]. It is imperative to stipulate a UHI based on specifying the LCZ for urban and rural, if individual sites are used, especially in a long-term trend analysis. A classification of the nature of the rural reference site is recommended, striving to make it be representative of a relatively stable, unchanging, natural environment of the region. In [38], researchers developed a simulation of diurnal temperature range (DTR) outcomes for 
various LCZs in urban areas in comparison with a rural dry area-an LCZ D. An LCZ E (similar to that used in the present study) was analyzed relative to a rural area (similar to the present analysis) and resulted in decreases of DTR of ca. $7{ }^{\circ} \mathrm{C}$ [38]. With smaller $\mathrm{T}_{\operatorname{maxU}-\mathrm{R}}$ changes than $\mathrm{T}_{\text {minU-R }}$ over time at Las Vegas and Phoenix shown in this analysis, the DTRs at these airports averaged over the last 10 years have reduced by $7.8^{\circ} \mathrm{C}$ and $6.0^{\circ} \mathrm{C}$, respectively, similar to the analysis of [38].

The above analysis at the division level and individual site level points to large temperature changes in the SW desert region. Regional signals of change are substantial, as indicated by rural changes of ca. $2.0^{\circ} \mathrm{C}$ and $2.5^{\circ} \mathrm{C}$ for June maximum and minimum temperatures. Urban areas, in many ways, are already experiencing some general scenario predictions of future temperature changes for the SW USA, with $>5^{\circ} \mathrm{C}$ changes. The results here do not point to any relaxing of temperature trends overall for this ca. 70-year period, generally similar to findings of [39]. However, understanding metadata in evaluations of trends of individual sites remains critical in interpretations of results. Important details over the time period need to be further assessed, especially high-resolution land cover around sites within $500 \mathrm{~m}$ of sensors. Furthermore, wholesale changes in sensors have occurred in the NOAA national network, and many station moves may affect results (the sites of \#6, 10, and 13 in Figure 1 are cases in point, where although the records are long, there have been many station moves, and rates of change are questionable). A great deal of effort is underway to address urban mitigation of extreme temperatures, and academics and stakeholders are developing plans to cope with expected increases in heat effects for the future [12,40-48]. A combination of historical assessments as to where we have been, together with forward-looking analysis using scenario constructs and verifiable modeling in concert with local stakeholder engagement, will likely aid in addressing climate issues in this critical and rapidly growing desert environment in the SW USA.

Funding: This research received no external funding.

Acknowledgments: I thank several people who provided ideas and/or data for this paper. Scott Sheridan, Department of Geography, Kent State University, provided access to weather type data for desert SW USA sites. Iain Stewart, Global Cities Institute, University of Toronto, Toronto, CA, provided insights on representing urban effects. John Blair, currently University New South Wales Built Environment, Sydney, AU, and Matthew J. Taylor, Department of Geography and the Environment, University of Denver, Denver, CO, worked on ideas with earlier data in an Arizona State University graduate seminar that has stimulated this research. Hannah Mensing, former Honors student in Geography at Arizona State University, wrote a BA thesis on investigating urban effects at some sites in the desert SW and helped stimulate this effort. Barbara Trapido-Lurie, School of Geographical Sciences and Urban Planning, who works on realms of cartographic design, geographic information technologies, aided in all figures. Map and GIS specialists at ASU's Library Map and Geospatial Hub assisted with identifying sources of land cover imagery.

Conflicts of Interest: The author declares no conflict of interest.

\section{References}

1. Wuebbles, D.J.; Fahey, D.W.; Hibbard, K.A.; Dokken, D.J.; Stewart, B.C.; Maycock, T.K. (Eds.) Climate Science Special Report: Fourth National Climate Assessment, Volume I; U.S. Global Change Research Program: Washington, DC, USA, 2017.

2. Cayan, D.R.; Douglas, A.V. Urban influences on surface temperatures in the southwestern United States during recent decades. J. Clim. Appl. Meteorol. 1984, 23, 1520-1530. [CrossRef]

3. Karl, T.R.; Diaz, H.F.; Kukla, G. Urbanization: Its detection and effect in the United States climate record. J. Clim. 1988, 1, 1099-1123. [CrossRef]

4. Kamal, S.; Huang, H.-P.; Myint, S.W. The Influence of Urbanization on the Climate of the Las Vegas Metropolitan Area: A Numerical Study. J. Appl. Meteorol. Climatol. 2015, 54, 2157-2177. [CrossRef]

5. Chow, W.T.L.; Brennan, D.; Brazel, A.J. Urban heat island research in Phoenix, Arizona, theoretical contributions and policy applications. Bull. Am. Meteorol. Soc. 2012, 93, 517-530. [CrossRef]

6. Georgescu, M.; Miguez-Macho, G.; Steyaert, L.T.; Weaver, C.P. Sensitivity of summer climate to anthropogenic land-cover change over the greater Phoenix, Arizona, region. J. Arid Environ. 2008, 72, 1358-1373. [CrossRef]

7. Comrie, A.C. Mapping a wind-modified urban heat island in Tucson, Arizona (with comments on integrating research and undergraduate learning). Bull. Am. Meteorol. Soc. 2000, 81, 2417-2431. [CrossRef] 
8. Georgescu, M.; Moustaoui, M.; Mahalov, A.; Dudhia, J. Summer-time climate impacts of projected megapolitan expansion in Arizona. Nat. Clim. Chang. 2013, 3, 37-41. [CrossRef]

9. Garfin, G.; Jardine, A.; Merideth, R.; Black, M.; LeRoy, S. (Eds.) Assessment of Climate Change in the Southwest United States: A Report Prepared for the National Climate Assessment. In A Report by the Southwest Climate Alliance; Island Press: Washington, DC, USA, 2013.

10. Baker, L.C.; Brazel, A.J.; Selover, N.; Martin, C.; McIntyre, N.; Steiner, F.R.; Nelson, A.; Mussacchio, L. Urbanization and warming of Phoenix (Arizona, USA): Impacts, feedbacks, and mitigation. Urban Ecosyst. 2002, 6, 183-203. [CrossRef]

11. MacDonald, G.M. Water, climate change, and sustainability in the southwest. Proc. Natl. Acad. Sci. USA 2010, 107, 21256-21262. [CrossRef]

12. CitiesIPCC. Available online: https://citiesipcc.org/beyond/campaign/ (accessed on 1 November 2019).

13. National Centers for Environmental Information, Divisional Data. Available online: https://www.ncdc.noaa. gov/cag/divisional/time-series (accessed on 1 November 2019).

14. National Centers for Environmental Information, Climate Data Online-Individual Sites. Dataset Description Document Global Summary of the Month/Year Dataset Version 1.0.1 / March 27, 2017. Available online: https://www.ncdc.noaa.gov/cdo-web/ (accessed on 1 November 2019).

15. Brazel, A.J. Scales of Climate in Designing with the desert. In Design with the Desert, Conservation and Sustainable Development; Malloy, R., Brock, J., Floyd, A., Livingston, M., Webb, R.H., Eds.; CRC Press: Boca Raton, USA, 2013.

16. Sheppard, P.R.; Comrie, A.C.; Packin, G.D.; Angersbach, K.; Hughes, M.K. The climate of the US Southwest. Clim. Res. 2002, 21, 219-238. [CrossRef]

17. Sheridan, S.C. The Redevelopment of a weather-type classification scheme for North America. Int. J. Climatol. J. R. Meteorol. Soc. 2002, 22, 51-68. [CrossRef]

18. Oke, T.R. Initial guidance to obtain representative meteorological observations at urban sites. In Instruments and Methods of Observation Programme; 10M Report No. 81, WMO/TD No. 1250; World Meteorological Organization: Geneva, Switzerland, 2004; p. 51.

19. Durre, I.; Menne, M.J.; Gleason, B.E.; Houston, T.G.; Vose, R.S. Comprehensive automated quality assurance of daily surface observations. J. Appl. Meteorol. Climatol. 2010, 49, 1615-1633. [CrossRef]

20. Menne, M.J.; Williams, C.N., Jr.; Palecki, M.A. On the reliability of the U.S. surface temperature record. J. Geophys. Res. Atmos. 2010, 115, D11108. [CrossRef]

21. Menne, M.J.; Durre, I.; Vose, R.S.; Gleason, B.E.; Houston, T.G. An Overview of the Global Historical Climatology Network-Daily Database. J. Atmos. Ocean. Technol. 2012, 29, 897-910. [CrossRef]

22. Lawrimore, J.H.; Ray, R.; Applequist, S.; Korzeniewski, B.; Menne, M.J. Global Summary of the Month (GSOM), version 1; NOAA National Centers for Environmental Information: Silver Spring, MD, USA, 2016.

23. MRLC Project and Land Cover (U.S. Geological Survey (USGS) Earth Resources Observation and Science (EROS) Center. Available online: https://www.mrlc.gov/data (accessed on 1 November 2019).

24. MesoWest University of Utah Atmospheric Sciences. Available online: https://mesowest.utah.edu (accessed on 1 November 2019).

25. Brightness Index from NASA Goddard Institute for Space Studies. Available online: https://data.giss.nasa. gov/cgi-bin/gistemp/ (accessed on 1 November 2019).

26. Svoma, B.M.; Brazel, A.J. Urban effects on the diurnal temperature cycle in Phoenix, Arizona. Clim. Res. 2010, 41, 21-29. [CrossRef]

27. Historical Aerial Photography Maricopa County. Available online: https://gis.maricopa.gov/GIO/ HistoricalAerial/index.html (accessed on 1 November 2019).

28. Historical Photos UC Santa Barbara Library California Aerial Photography by County. Available online: https://www.library.ucsb.edu/src/airphotos/california-aerial-photography-county (accessed on 1 November 2019).

29. Stewart, I.D.; Oke, T.R. Local climate zones for urban temperature studies. Bull. Am. Meteorol. Soc. 2012, 93, 1880-1900. [CrossRef]

30. Wang, C.; Middel, A.; Myint, S.W.; Kaplan, S.; Brazel, A.J.; Lukasczyk, J. Assessing local climate zones in arid cities: The case of Phoenix, Arizona and Las Vegas, Nevada. ISPRS J. Photogramm. Remote Sens. 2018, 141, 59-71. [CrossRef] 
31. Hawkins, T.W.; Brazel, A.J.; Stefanov, W.L.; Bigler, W.; Saffell, E.M. The role of rural variability in urban heat island determination for Phoenix, Arizona. J. Appl. Meteorol. 2004, 43, 476-486. [CrossRef]

32. Scott Sheridan Website. Available online: http://sheridan.geog.kent.edu/ssc.html (accessed on 1 November 2019).

33. Brazel, A.; Gober, P.; Lee, S.-J.; Grossman-Clarke, S.; Zehnder, J.; Hedquist, B.; Comparri, E. Determinants of changes in the regional urban heat island in metropolitan Phoenix (Arizona, USA) between 1990 and 2004. Clim. Res. 2007, 33, 171-182. [CrossRef]

34. Stone Jr, B. Short Communication Urban and rural temperature trends in proximity to large US cities: 1951-2000. Int. J. Clim. 2007, 27, 1801-1807. [CrossRef]

35. Gall, R.; Young, K.; Schotland, R.; Schmitz, J. The recent maximum temperature anomalies in Tucson: Are they real or an instrumental problem? J. Clim. 1992, 5, 657-665. [CrossRef]

36. Roth, M. Review of urban climate research in (Sub) tropical regions. Int. J. Clim. 2007, 27, 1859-1873. [CrossRef]

37. Brazel, A.J.; Selover, N.; Vose, R.; Heisler, G. Tale of two climates-Baltimore and Phoenix urban LTER sites. Clim. Res. 2000, 15, 123-135. [CrossRef]

38. Stewart, I.D.; Oke, T.R.; Krayenhoff, E.S. Evaluation of the 'local climate zone' scheme using temperature observations and model simulations. Int. J. Clim. 2014, 34, 1062-1080. [CrossRef]

39. Karl, T.R.; Arguez, A.; Huang, B.; Lawrimore, J.H.; McMahon, J.R.; Menne, M.J.; Peterson, T.C.; Vose, R.S.; Zhang, H.-M. Possible artifacts of data biases in the recent global surface warming hiatus. Science 2015, aaa5632. [CrossRef]

40. Chow, W.T.L.; Chuang, W.-C.; Gober, P. Vulnerability to Extreme Heat in Metropolitan Phoenix: Spatial, Temporal, and Demographic Dimensions. Prof. Geogr. 2012, 64, 286-302. [CrossRef]

41. Chow, W.T.L.; Brazel, A.J. Assessing xeriscaping as a sustainable heat island mitigation approach for a desert city. Build. Environ. 2012, 47, 170-181. [CrossRef]

42. City of Phoenix, 2008: Sustainable Development in A Desert Climate. Downtown Phoenix Plan, City of Phoenix. 2008. Available online: http://phoenix.gov/urbanformproject/dtplan.html (accessed on 1 November 2019).

43. City of Phoenix, the Tree and Shade Master Plan. Available online: https:/resilientwest.org/case-study/ phoenix-az-tree-and-shade-master-plan/ (accessed on 1 November 2019).

44. Habeeb, D.; Jason Vargo, J.; Stone, B., Jr. Rising heat wave trends in large US cities. Nat. Hazards 2015, 76, 1651-1665. [CrossRef]

45. Stone, B.; Vargo, J.; Habeeb, D. Managing climate change in cities: Will climate actions plans work? Landsc. Urban Plan. 2012, 107, 263-271. [CrossRef]

46. Stoker, P.; Chang, H.; Wentz, E.; Crow-Miller, B.; Jehle, G.; Bonnette, M. Building Water-Efficient Cities. J. Am. Plan. Assoc. 2019. [CrossRef]

47. Krayenhoff, E.S.; Moustaoui, M.; Broadbent, A.; Gupta, V.; Georgescu, M. Diurnal interaction between urban expansion, climate change and adaptation in US cities. Nat. Clim. Chang 2018, 8, 1097-1103. [CrossRef]

48. Chuang, W.-C.; Karner, A.; Selover, N.; Hondula, D.; Chhetri, N.; Middel, A.M.; Roach, M.; Dufour, N. Arizona Extreme Weather, Climate and Health Profile Report; Arizona State University Press: Tempe, AZ, USA, 2015.

(C) 2019 by the author. Licensee MDPI, Basel, Switzerland. This article is an open access article distributed under the terms and conditions of the Creative Commons Attribution (CC BY) license (http://creativecommons.org/licenses/by/4.0/). 